\title{
SUSCEPTIBILITY OF Picea abies AND Pinus sylvestris SEEDLINGS OF VARIOUS ORIGINS TO Heterobasidion annosum AND H. parviporum
}

\author{
Astra Zaluma ${ }^{1,2}$, Arnis Gailis ${ }^{1}$, Natālija Burṇeviča ${ }^{1}$, Kari Korhonen ${ }^{3}$, \\ and Tālis Gaitnieks ${ }^{1,2 \#}$ \\ ${ }^{1}$ Latvian State Forest Research Institute Silava, P.O., Rīgas 111, Salaspils, LV-2169, LATVIA \\ 2 Forest Sector Competence Center, LLC "MNKC", Dzērbenes iela 27, Rīga, LV-1006, LATVIA \\ ${ }^{3}$ Natural Resources Institute Finland, Southern Unit, P.O. Box 18, FI-01301 Vantaa, FINLAND \\ \# Corresponding author; talis.gaitnieks@silava.lv
}

Contributed by Tālis Gaitnieks

Five-year-old Norway spruce and four-year-old Scots pine seedlings of various origin were inoculated with Heterobasidion annosum s.s. and $\mathrm{H}$. parviporum to estimate whether the susceptibility of seedlings to Heterobasidion was affected by origin of seeds. In total, 520 spruce and 538 pine seedlings from different seed sources and provenance regions of Latvia were tested. Four months after inoculation the fungal growth was measured. The results highlight differences between development of $\mathrm{H}$. annosum and $\mathrm{H}$. parviporum in spruce and pine seedlings. We did not find any seed source that was more resistant than others.

Key words: pine, spruce, Heterobasidion root rot, resistance test.

\section{INTRODUCTION}

Norway spruce (Picea abies (L.) H. Karst) forests of Latvia are divided into three geographically distinct provenance regions and Scots pine (Pinus sylvestris L.) forests into two (Fig. 1). The provenances differ from each other in productivity and quality, such as in stem straightness and branch thickness (Baumanis u.c., 2001). In establishing new plantations local seedlings are recommended, because they may be better adapted to site conditions and more resistant to pathogens (Gonthier and Thor, 2013). It is known that environmental factors can influence tree susceptibility to fungal pathogens (Lindberg and Johansson, 1992; Santini et al., 1997; Karlsson et al., 2008)).

Root and butt rot caused by several species of Heterobasidion is one of the most destructive diseases of conifers in the northern temperate regions (Gonthier and Thor, 2013). In Latvia, a sample of 25000 stumps of Norway spruce was investigated (Arhipova et al., 2011); 21.8\% of them contained butt rot. Heterobasidion parviporum Niemelä \& Korhonen was the most common decay-causing fungus. Another Heterobasidion species, H. annosum (Fr.) Bref. sensu stricto, is common in Scots pine stands of Latvia but occurs also on spruce (McLaughlin and Šica, 1993; Zal̦uma et al., 2015).

Adaptation of $H$. parviporum for growth in spruce is well documented (Swedjemark et al., 2007) and it has been

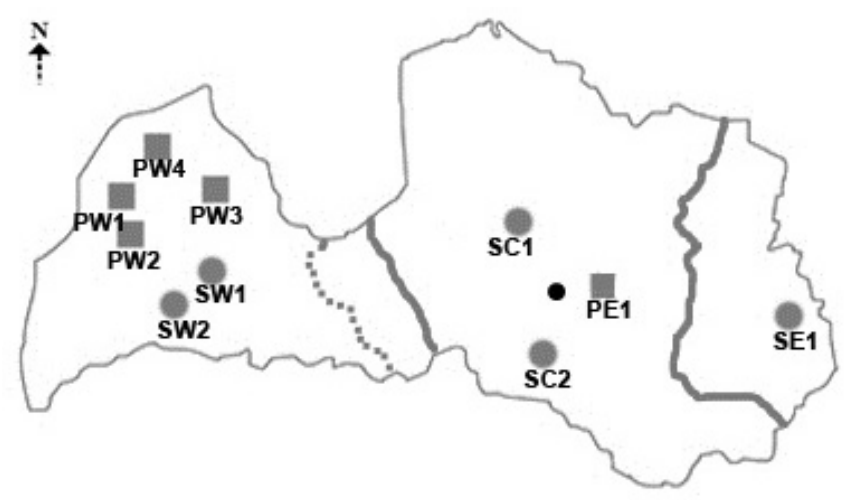

Fig. 1. Seed sources and provenance regions for Pinus sylvestris and Picea abies in Latvia. Dashed line separates provenance regions of $P$. sylvestris and solid line separates provenance regions of $P$. abies. Grey square seed source of $P$. sylvestris, grey circle - seed source of $P$. abies, black circle - Forest Research station in Jaunkalsnava.

shown that fungal growth in sapwood varies significantly between spruce clones (Swedjemark et al., 1997; Swedjemark and Stenlid, 1997) and families (Swedjemark and Karlsson, 2004; Skrøppa et al., 2015). In many artificial inoculation experiments, the growth rate of many isolates of Heterobasidion in $P$. abies and $P$. sylvestris seedlings has been investigated in relation to the virulence of the pathogen (Swedjemark et al., 1999). In order to test a wide collection of seedlings and origins we used only one isolate of 
CHARACTERISTICS OF Pinus sylvestris AND Picea abies SEEDLINGS USED IN THE STUDY

\begin{tabular}{|c|c|c|c|c|c|}
\hline \multirow[t]{2}{*}{ Tree species } & \multirow{2}{*}{$\begin{array}{l}\text { Provenance } \\
\text { region }\end{array}$} & \multirow[t]{2}{*}{ Seed source (coordinates) } & \multirow{2}{*}{$\begin{array}{c}\text { Number of } \\
\text { seedlings }\end{array}$} & \multicolumn{2}{|c|}{ Code } \\
\hline & & & & $\begin{array}{c}\text { Provenance } \\
\text { region }\end{array}$ & Seed source \\
\hline P. sylvestris* & Eastern & Sāvienas seed orchard (N 56.4093, E 26.0465) & 84 & $\mathrm{PE}$ & PE1 \\
\hline P. sylvestris* & Western & Zlēkas seed orchard (N 56.4910, E 24.5547) & 84 & PW & PW1 \\
\hline P. sylvestris* & & Dravas seed orchard (N 57.0357, E 21.5641) & 89 & & PW2 \\
\hline P. sylvestris & & Ezernieki seed orchard (N 57.2058, E 21.5658) & 105 & & PW4 \\
\hline P. abies* & Eastern & Ludza forest district, Ludza forestry (N 56.30, E 27.45) & 107 & SE & SE1 \\
\hline P. abies* & Western & Remte seed orchard (N 56.4477, E 22.4745) & 99 & SW & SW1 \\
\hline P. abies* & & Saldus forest district, Sesile forestry (N 56.36, E 21.35). & 106 & & SW2 \\
\hline P. abies* & Central & Cēsis forest district, Zaube forestry (N 57.02, E 25.45) & 108 & SC & $\mathrm{SC} 1$ \\
\hline
\end{tabular}

* Seedlings used also in earlier experiment (Zaluma et al., 2015)

$H$. annosum and $H$. parviporum in inoculation experiments. The aim of this study was to compare the development of $H$. annosum s.s. and $H$. parviporum in spruce and pine seedlings, and to determine whether the susceptibility of seedlings to Heterobasidion is affected by origin of seedlings.

\section{MATERIALS AND METHODS}

Plant material. In the experiment, 520 five-year-old spruce seedlings from five seed sources and 538 four-year-old pine seedlings from five seed sources were used (Table 1, Fig 1). All seedlings were cultivated in the experimental forest nursery of the Forest Research Station in Jaunkalsnava $\left(56^{\circ} 68^{\prime} \mathrm{N}, 25^{\circ} 96^{\prime} \mathrm{E}\right)$ (Fig. 1) under field conditions (Zaḷma et al., 2015).

Fungal isolates. The isolates were selected on the basis of strong disease symptoms that these fungal genotypes caused in the forest from which they were isolated. Heterokaryotic pure culture of $H$. parviporum (strain S37) was isolated in central Latvia from living $P$. abies with a long decay column extending up to $9.8 \mathrm{~m}$ (Arhipova et al., 2011). Heterokaryotic culture of $H$. annosum s.s. (VStr2821aP) represented a genotype that had infected seven $P$. sylvestris trees within a 9-m radius in eastern Latvia (K. Pāruma, unpublished data). The pure cultures were identified by pairing with homokaryotic tester isolates (Korhonen, 1978).

Inoculation of seedlings. Inoculum (pieces of spruce sapwood) was prepared using a procedure of Swedjemark and Stenlid (1995); the only difference was the size of the inoculum: length $0.8 \mathrm{~cm}$ and diameter $0.3-0.4 \mathrm{~cm}$. For inoculation, the lower part of the seedling stem was surface disinfected with $70 \%$ ethanol. A circular wound (diameter 0.4 $\mathrm{cm}$, depth $0.5 \mathrm{~cm}$ ) was made $1-2 \mathrm{~cm}$ above the soil surface using a disinfected drill positioned at an angle 45 degrees to the surface. A wood block colonised by Heterobasidion was inserted into the wound, which was then covered and sealed with gardening wax. Controls were treated similarly, using sterile wood blocks (Zaluma et al., 2015). A total of 213 pine seedlings and 201 spruce seedlings were inoculated with $H$. annosum; 216 pine seedlings and 199 spruce seedlings were inoculated with $H$. parviporum. As controls we used 109 pine and 120 spruce seedlings. Plants were grown under normal field conditions and regularly watered (1-2 times per week) until harvested. The experiment was started in 13 September, 2011. Mean air temperature was $13.6^{\circ} \mathrm{C}$ in September, $8.7{ }^{\circ} \mathrm{C}$ in October, $5.1{ }^{\circ} \mathrm{C}$ in November, $2.6{ }^{\circ} \mathrm{C}$ in December and $1.2{ }^{\circ} \mathrm{C}$ in the beginning of January, according to data from LLC "Latvijas, Vides, ǵeoloǵijas un meteoroloǵijas centrs" (Latvian Environment, Geology and Meteorology Centre).

Sampling. In 12 January 2012, plants were removed from pots, and their length and diameter at root collar were measured. The spread of fungus above and below the point of inoculation was also measured. Plants were cut at root collar level, branches were removed, and the stem surface was flamed to sterilise. An approximately $15-20-\mathrm{cm}$ long piece from stem base was cut into $0.2-1.1-\mathrm{cm}$ thick discs with disinfected secateurs. The discs were surface sterilised by quick flaming and placed on moist sterile filter paper in Petri dishes. After seven days incubation at room temperature, the discs were examined under stereo microscope for conidiophores of Heterobasidion. Re-isolation of inoculated isolate was attempted from 10 pine and 10 spruce plants; half of them had been inoculated with $H$. annosum and the other half with $H$. parviporum (Zalıma et al., 2015). Obtained isolates were paired with the original strain on malt agar medium to test for somatic compatibility (Stenlid, 1985).

At the time of sampling, Heterobasidion had already spread outside of the sampled region (upwards or downwards or both) in stems of 123 spruce seedlings. These seedlings were excluded from calculations concerning differences in spread of mycelium in different directions. Mean growth upwards, downwards and total longitudinal growth in both 
tree species and in each seed source was calculated. Total longitudinal growth of Heterobasidion was calculated also for spruce and pine in each provenance region.

Statistical analysis. Kruskal-Wallis chi-squared and MannWitney U, Tukey HSD tests were used to test for differences in growth of Heterobasidion. Graphical and mathematical processing and statistical analysis were carried out using Microsoft Excel 2010 and R version 3.1.2 (Anonymous, 2014).

\section{RESULTS}

Mean height of pine seedlings was $70.4 \mathrm{~cm} \pm 0.54 \mathrm{~cm}(\mathrm{n}=$ $538)$ and root collar diameter was $1.34 \mathrm{~cm} \pm 0.01 \mathrm{~cm}(\mathrm{n}=$ 538). Mean height of spruce seedlings was $70.7 \mathrm{~cm} \pm 0.58$ $\mathrm{cm}(\mathrm{n}=520)$ and root collar diameter was $1.38 \mathrm{~cm} \pm 0.01$ $\mathrm{cm}(\mathrm{n}=520)$. The differences between spruce and pine in diameter and height were not significant $(p>0.05)$.

Die-back of the inoculated and control seedlings was not observed during the incubation period. All re-isolations of the fungus from inoculated seedlings were vegetatively compatible with the inoculated strain, indicating that the re-isolated strain was identical with the inoculated one.

Both Heterobasidion species spread significantly faster in spruce than in pine (Table 2). In spruce, $H$. parviporum was slightly but not significantly faster than $H$. annosum, and both Heterobasidion species spread significantly faster upward from the inoculation point (Table 3 ). In pine, H. annosum spread significantly faster than $H$. parviporum, and the spreading of both species was slightly but not significantly faster downward.

Growth of Heterobasidion in seedlings from different seed sources. Pine. In pine seedlings, growth of $H$. annosum was significantly faster in seedlings from the western seed source PW3 compared to eastern PE1, but between other seed sources of pine we did not detect significant differences. Also, the growth of $H$. parviporum was fairly similar in all pine seed sources (Fig. 2).

Spruce. In spruce seedlings, growth of $H$. annosum was a little faster in western seed sources SW1 and SW2 compared to central and eastern ones $\mathrm{SC} 1, \mathrm{SC} 2$ and $\mathrm{SE} 1$, but the
Table 2

MEAN LONGITUDINAL GROWTH OF Heterobasidion annosum AND H. parviporum IN SEEDLINGS OF Pinus sylvestris AND Picea abies

\begin{tabular}{l|c|c}
\hline \multirow{2}{*}{ Species } & \multicolumn{2}{c}{ Growth of Heterobasidion $\pm \mathrm{SE}, \mathrm{cm}^{*}$} \\
\cline { 2 - 3 } & P. sylvestris & P. abies \\
\hline H. annosum & $1.78 \pm 0.07 \mathrm{a}$ & $7.73 \pm 0.25 \mathrm{c}$ \\
H. parviporum & $1.24 \pm 0.06 \mathrm{~b}$ & $8.03 \pm 0.24 \mathrm{c}$
\end{tabular}

*For each variable, means with different letter subscripts, whether in rows or column, are significantly different $(p<0.05)$. SE, standard error.

$$
\text { Table } 3 \text {. }
$$

MEAN GROWTH OF Heterobasidion annosum AND $H$. parviporum IN SEEDLINGS OF Pinus sylvestris AND Picea abies UPWARD AND DOWNWARD FROM INOCULATION POINT

\begin{tabular}{l|c|c|c|c}
\hline \multirow{2}{*}{} & $\begin{array}{c}\text { Growth in P. sylvestris } \pm \mathrm{SE}, \\
\mathrm{cm} *\end{array}$ & $\begin{array}{r}\text { Growth in P. abies } \pm \mathrm{SE}, \\
\mathrm{cm} *\end{array}$ \\
\cline { 2 - 5 } & Upward & Downward & Upward & Downward \\
\hline H. annosum & $0.87 \pm 0.04 \mathrm{a}$ & $0.92 \pm 0.04 \mathrm{a}$ & $3.57 \pm 0.18 \mathrm{~b}$ & $2.76 \pm 0.23 \mathrm{~d}$ \\
H. parviporum & $0.62 \pm 0.04 \mathrm{a}$ & $0.63 \pm 0.04 \mathrm{ab}$ & $3.62 \pm 0.11 \mathrm{c}$ & $3.09 \pm 0.11 \mathrm{e}$
\end{tabular}

*For each variable, means with different letter subscripts, whether in rows or column, are significantly different $(p<0.05)$. SE, standard error.

differences were not significant. $H$. parviporum spread significantly faster in SW2 seedlings compared to SC, and in SE1 seedlings compared to SC1, SC2, and SW1. Differences between seedlings from other sources were not significant (Fig. 2).

Growth of Heterobasidion in seedlings from different provenance regions. Pine. There were no significant differences in the growth of Heterobasidion species in pine seedlings from different provenance regions. H. annosum grew slightly faster in western PW seedlings in comparison to eastern PE seedlings, and H. parviporum grew faster in PE compared to PW seedlings $(p=0.079)$ (Table 4$)$.

Spruce. H. annosum spread significantly faster in SW seedlings compared to SC seedlings, while there was no significant difference between SW and SE seedlings $(p=0.065)$ and between SC and SE seedlings. Growth of $H$. parviporum was significantly faster in SE seedlings than in SC

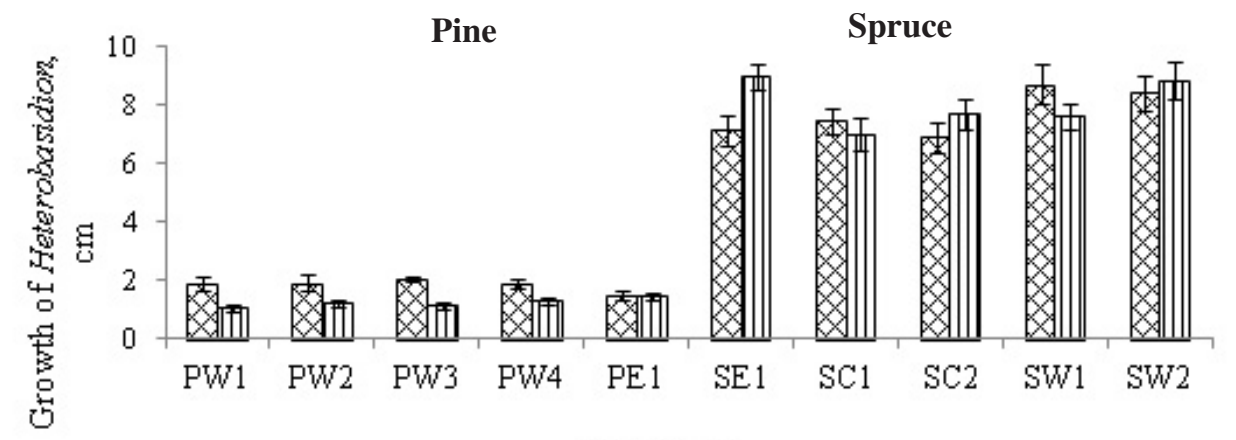

Seed source

由. annosum s.s. 四 H. pariporum
Fig. 2. Mean longitudinal growth of Heterobasidion annosum and $H$. parviporum (in 122 days) in different seed sources of Pinus sylvestris and Picea abies, standard error included. 
Table 4 .

MEAN LONGITUDINAL GROWTH OF Heterobasidion annosum AND H. parviporum IN SEEDLINGS OF Pinus sylvestris AND Picea abies FROM DIFFERENT PROVENANCE REGIONS

\begin{tabular}{l|c|c}
\hline \multirow{2}{*}{$\begin{array}{c}\text { Seed } \\
\text { source }\end{array}$} & H. annosum & H. parviporum \\
\cline { 2 - 3 } & $\begin{array}{c}\text { Growth of Heterobasidion } \pm \\
\text { SE, cm* }\end{array}$ & $\begin{array}{c}\text { Growth of Heterobasidion } \pm \\
\text { SE, cm* }\end{array}$ \\
\hline PW & $1.84 \pm 0.07 \mathrm{a}$ & $1.20 \pm 0.06 \mathrm{~b}$ \\
PE & $1.52 \pm 0.15 \mathrm{~b}$ & $1.47 \pm 0.05 \mathrm{~b}$ \\
SW & $8.57 \pm 0.45 \mathrm{ce}$ & $8.25 \pm 0.40 \mathrm{cde}$ \\
SC & $7.18 \pm 0.33 \mathrm{~d}$ & $7.34 \pm 0.38 \mathrm{~d}$ \\
SE & $7.15 \pm 0.54 \mathrm{~cd}$ & $9.00 \pm 0.45 \mathrm{e}$ \\
\hline
\end{tabular}

*For each variable, means with different letter subscripts, whether in rows or column, are significantly different $(p<0.05)$. SE, standard error.

seedlings and slightly faster than in SW seedlings ( $p=$ 0.082) (Table 4).

\section{DISCUSSION}

In the present work seedlings were inoculated by Heterobasidion through stem wounds, but in nature Heterobasidion invades conifer stands by basidiospores through newly cut stumps or fresh wounds on roots. Stem wounds are colonised only occasionally (Redfern and Stenlid, 1998). However, stem wound infection may be more significant in unmanaged forests, where fresh stumps are rare or absent (Garbelotto and Gonthier, 2013).

Although high mortality has been observed in many experiments with Heterobasidion (Swedjemark and Stenlid, 1995; Swedjemark et al. 1999; Werner and Łakomy, 2002), we did not observe any seedling die-back or external symptoms like wilting and needle discolorations in our experiment. Relatively low mortality of seedlings may be explained with low virulence of the pathogen (Kuhlman, 1970; Worrall et al., 1983; Łakomy et al., 2011) or short incubation period (Worrall et al., 1983; Swedjemark et al., 2001). The mortality rate increases with length of incubation period. For example, the mortality rate of four-year-old clones of $P$. abies inoculated with $H$. parviporum and incubated at $18{ }^{\circ} \mathrm{C}$ was $0.5 \%$ after 34 days, and $20 \%$ after 83 days (Swedjemark et al., 2001). In our experiment the incubation period (122 days) was longer; but average air temperature was lower; so we do not consider that the incubation period was insufficient to cause seedling mortality. Kuhlman (1970) showed that Heterobasidion with low virulence is often replaced by Trichoderma (in that experiment inoculation holes were made in the root collar). In our research we did not observe the replacement of Heterobasidion by Trichoderma. Also, an important factor in susceptibility to Heterobasidion is vitality of seedlings (Swedjemark and Stenlid, 1997). In their earlier inoculation experiment, where the seedlings of spruce had undeveloped root systems, the mortality caused by Heterobasidion was high (Swedjemark and Stenlid 1995).
The growth of both Heterobasidion species in spruce seedlings was significantly faster than in pine seedlings, and in spruce seedlings the fungus spread more rapidly upwards. In pine seedlings the situation was rather the opposite. This is mainly in agreement with observations made in other studies (Stenlid and Swedjemark, 1988; Lindberg, 1992; Swedjemark and Stenlid, 1995; Swedjemark et al., 1999). In mature spruce Heterobasidion often spreads high up in the stem, up to $12 \mathrm{~m}$ (Stenlid and Wästerlund, 1986), but in pine the growth of Heterobasidion is usually restricted to the stem base (Korhonen and Stenlid, 1998). Results of our research show that Heterobasidion infection in inoculated seedlings spreads in a comparable way, although seedlings do not contain heartwood.

Our results confirm that $H$. annosum is better adapted to $P$. sylvestris, and $H$. parviporum to $P$. abies (partly presented also in Zaluma et al., 2015), as observed previously in inoculation experiments (Stenlid and Swedjemark, 1988; Lindberg, 1992). Similar observations have been made in field conditions. For example, the spread of $H$. parviporum in stems of 60-year-old $P$. abies in Lithuania was more extensive than spread of $H$. annosum: $4.59 \pm 1.59 \mathrm{~m}$ and 3.27 $\pm 1.01 \mathrm{~m}$, respectively (Vasiliauskas and Stenlid, 1998).

We did not find any seed source that was distinctly more resistant than others. Growth of Heterobasidion was about similar in seedlings from the same provenance region, but slight differences occurred between different provenance regions (Table 4). Our results showed that spruce seedlings originating from western and eastern Latvia, and cultivated outside their own provenance region in Jaunkalsnava, central Latvia, were characterized by a higher growth rate of $H$. parviporum, suggesting lower resistance and possibly indicating lower adaption to environmental conditions. This difference may be mainly due to local climatic conditions, as all the seedlings were cultivated in forest nursery. Resistance against pathogens and pathogen growth rate in wood may change in different environments (Lindberg and Johansson, 1992; Santini et al., 1997).

Our research highlights differences between development of Heterobasidion annosum and $H$. parviporum in spruce and pine seedlings and show that these differences correspond to the behaviour of these fungi also in mature trees. There is some evidence that differences in susceptibility against Heterobasidion might be found between different origins of seeds. This should be considered when regenerating stands on soils that are infected with Heterobasidion as well as in planting of new stands on former agriculture land.

\section{ACKNOWLEDGEMENTS}

This study was supported by the JSC "Latvian State Forests" project "Investigation of the factors limiting the spread of root rot" and ERDF funded project (No. L-KC11-0004) „Methods and technologies for increasing forest capital value". We thank Prof. Guntis Brümelis for assistance with language revision. We thank L. Brūna, 
D. Kḷaviņa, K. Kenigsvalde, D. Nitiša, P. Sedlak, I. DruvaLūsìte for assistance in laboratory work.

\section{REFERENCES}

Anonymous (2014). R Core Team: A language and environment for statistical computing [computer software]. R Foundation for Statistical Computing, Vienna, Austria.

Arhipova, N., Gaitnieks, T., Donis, J., Stenlid, J., Vasaitis, R. (2011). Butt rot incidence, causal fungi and related yield loss in Picea abies stands of Latvia. Can. J. For. Res., 41 (12), 2337-2345.

Baumanis, I., Gailis, A., Liepiņš, K. (2001). Latvijas priežu provenienču salīdzinājums. [Comparison of Scots pine provenances in Latvia]. Mežzinātne, 45, 52-66 (in Latvian).

Garbelotto, M., Gonthier, P. (2013). Biology, epidemiology and control of Heterobasidion species worldwide. Annu. Rev. Phytopathol., 51, 39-59.

Gonthier, P., Thor, M. (2013). Annosus root and butt rots. In: Gonthier, P., Nicolotti, G. (Eds.). Infectious Forest Diseases. CABI, Wallingford, UK, pp. $128-158$.

Karlsson, B., Tsopelas, P., Zamponi, L., Capretti, P., Soulioti, N. (2008). Susceptibility to Heterobasidion parviporum in Picea abies clones grown in different environments. For. Pathol., 38 (2), 73-145.

Korhonen, K. (1978). Intersterility groups of Heterobasidion annosum. Comm. Inst. For. Fenn., 94 (6), 1-25.

Korhonen, K., Stenlid, J. (1998). Biology of Heterobasidion annosum. In: Woodward, S., Stenlid, J., Karjalainen, R., Hüttermann, A. (Eds.). Heterobasidion annosum: Biology, Ecology, Impact and Control. CABI, Wallingford, pp. 43-70.

Kuhlman, E. G. (1970). Seedling inoculations with Fomes annosus show variation in virulence adn in host susceptibility. Phytopathology, 60, 1743-1746.

Łakomy, P., Kwaśna, H., Dalke-Świderska, M. (2011). The virulence of Heterobasidion parviporum population from Norway spruce stand in Suvałki forest district. Acta Sci. Pol. Silv. Colendar. Rat. Ind. Lignar., 10 (3), 27-36.

Lindberg, M. (1992). S and P intersterility groups in Heterobasidion annosum; Infection frequencies through bark of Picea abies and Pinus sylvestris seedlings and in vitro growth rates at different oxygen levels. Eur. J. For. Pathol., 22 (1), 41-45.

Lindberg, M., Johansson, M. (1992). Resistance of Picea abies seedlings to infection by Heterobasidion annosum in relation to drough stress. Eur. J. For. Pathol., 22 (2), 115-124.

McLaughlin, J. A., Šica, L. (1993). Growing pine in Latvia: Pathological considerations. Proc. Latvian Acad. Sci., Section B, Nr. 7, 49-56.

Redfern, D. B., Stenlid, J. (1998). Spore dispersal and infection. In: Woodward, S., Stenlid, J., Karjalainen, R., Hüttermann, A. (Eds.). Heterobasidion annosum: Biology, Ecology, Impact and Control. CABI, Wallingford, pp. 105-124.

Skrøppa, T., Solheim, H., Steffenrem, A. (2015). Genetic variation, inheritance patterns and parent-offspring relationships after artificial inoculations with Heterobasidion parviporum and Ceratosystis polonica in Norway spruce seed orchards and progeny tests. Silva Fenn., 49 (1), 1-12.
Santini, A., Casini, N., Di Lonardo, V., Raddi, P. (1997). Canker resistance stability of some Cupressus sempervirens clones to Seiridium cardinale [Tuscany]. J. Genet. Breed., 51, 269-277.

Stenlid, J. (1985). Population structure of Heterobasidion annosum as determined by somatic incompatibility, sexual incompatibility, and isoenzyme patterns. Can. J. Bot., 63 (12), 2268-2273.

Stenlid, J., Swedjemark, G. (1988). Differential growth of S- and P-isolates of Heterobasidion annosum in Picea abies and Pinus sylvestris. Trans. Brit. Mycol. Soc., 90 (2), 209-213.

Stenlid, J., Wästerlund, I. (1986). Estimating the frequency of stem rot in Picea abies using an increment borer. Scand. J. For. Res., 1 (1-4), 303-308.

Swedjemark, G., Johannesson, H., Stenlid, J. (1999). Intraspecific variation in Heterobasidion annosum for growth in sapwood of Picea abies and Pinus sylvestris. Eur. J. For. Pathol., 29 (4), 249-258.

Swedjemark, G., Stenlid, J. (1995). Susceptibility of conifer and broadleaf seedlings to Swedish S- and P-strains of Heterobasidion annosum under greenhouse conditions. Plant Pathol., 44 (1), 73-79.

Swedjemark, G., Stenlid, J. (1997). Between-tree and between-isolate variation for growth of S-group Heterobasidion annosum in sapwood of Picea abies cuttings. Can. J. For. Res., 27 (5), 711-715.

Swedjemark, G., Karlsson, B., 2004. Variation in incidence and genetic impact on natural infection of Heterobasidion annosum in Picea abies (L.) Karst. in genetic trials in south Sweden. For. Ecol. Manage., 203 (1-3), $135-145$.

Swedjemark, G., Stenlid, J., Karlsson, B. (1997). Genetic variation among clones of Picea abies in resistance to growth of Heterobasidion annosum. Silvae Genet., 46 (6), 369-374.

Swedjemark, G., Stenlid, J., Karlsson, B. (2001). Variation in growth of Heterobasidion annosum among clones of Picea abies incubated for different periods of time. For. Pathol., 31 (3), 163-175.

Swedjemark, G., Karlsson, B., Stenlid, J. (2007). Exclusion of Heterobasidion parviporum from inoculated clones of Picea abies and evidence of systemic induced resistance. Scand. J. For. Res., 22, 110-117.

Vasiliauskas, R., Stenlid, J., (1998). Spread of S and P group isolates of Heterobasidion annosum within and among Picea abies trees in central Lithuania. Can. J. For. Res., 28 (7), 961-966.

Werner, A., Łakomy, P. (2002). Host specialization of IS-group isolates of Heterobasidion annosum to Scots pine, Norway spruce and common fir in field inoculation experiments. Dendrobiology, 47, 59-68.

Worrall, J. J., Parmeter, J. R. Jr., Cobb, F. W. Jr. (1983). Host specialization of Heterobasidion annosum. Phytopathology, 73 (2), 304-307.

Zaḷuma, A., Jansons, Ā., Burņeviča, B., Baumanis, I., un Gaitnieks, T. (2015). Heterobasidion annosum s.l. sastopamība Pinus contorta var. latifolia stādījumos Latvijā. [Occurrence of Heterobasidion annosum s.1. in stands of Pinus contorta var. latifolia in Latvia]. Mežzinātne, 29, 56-67 (in Latvian).

Zalıuma, A., Gaitnieks, T., Arhipova, N., Vasaitis, R. (2015). Growth rates of Heterobasidion annosum s.s. and $H$. parviporum in functional sapwood of Pinus sylvestris and Picea abies. For. Pathol., 45 (5), 437-439.

Received 9 July 2015

\section{DAŽĀDAS IZCELSMES Pinus sylvestris UN Picea abies STĀDU UZN̦ĒMĪBA PRET Heterobasidion annosum UN H. parviporum}

Picea abies un Pinus sylvestris stādi tika mākslīgi inficēti ar Heterobasidion annosum un H. parviporum, lai noteiktu, vai stādu uzṇēmību pret Heterobasidion ietekmē sēklu izcelsmes vieta. Tika pārbaudīti 538 P. sylvestris un 520 P. abies stādi, kas reprezentēja atšḳirīgas sēklu plantācijas, dažādus reproduktīvā materiāla ievākšanas reǵionus Latvijā. Četrus mēnešus pēc stādu mākslīgās inficēšanas tika noteikta Heterobasidion micēlija izplatība stumbrā uz augšu un leju no inokulācijas vietas. Konstatēts, ka pastāv atšḳirības starp $H$. annosum un H. parviporum micēlija attīstību priežu un egḷu stādos. Salīdzinot abu patogēnu sugu augšanas ātrumu atškirīgas izcelsmes priežu un egḷu stādos, secināts, ka neviens no analizētajiem stādu variantiem neuzrādīja būtiski augstāku rezistenci pret $H$. annosum. 